\title{
Exploring Kyllinga vaginata Lam. : Results of Antibacterial Screening to Validate its Traditional use
}

\author{
Maria E Blanc $\mathbf{R}^{1}$, Ana M Gonzalez ${ }^{2}$, Bonifacia Benitez ${ }^{1}$, Miguel Martinez ${ }^{1}$, Muriel Sylvestre ${ }^{3}$ and Gerardo Cebrian \\ Torrejon $^{3 *}$
}

${ }^{1}$ Faculté des Sciences Exactes et Naturelles (FACEN), Université Nationale d'Asunción, Paraguay

${ }^{2} I B O N E$ (UNNE-CONICET), Facultad de Ciencias Agrarias, Argentine

${ }^{3}$ Laboratoire COVACHIM-M2E, EA 3592, Université des Antilles, France

Submission: January 20, 2022; Published: February 02, 2022

*Corresponding author: Gerardo Cebrian Torrejon, Laboratoire COVACHIM-M2E, EA 3592, Université des Antilles, 97157 Pointe-à-Pitre Cedex, France

\begin{abstract}
Paraguay, a country that has more than four centuries of experience in the use of hundreds of medicinal plants, many of them from the region, where we find the species popularly known as kapi' ikati, which in Guaraní language means "scent herb strong" and is marketed by the "yuyeras" (people dedicated to the sale of natural products). "Kapi'ikatî", in fact, encompasses at least four different species of the genus Kyllinga and one species of another genus Scleria distans Poir (Cyperaceae), which are marketed as diuretic, antispasmodic and diaphoretic, among others. One of the species used is Kyllinga vaginata Lam. (Cyperaceae) which is widely distributed in the country and of which only the rhizome is used in mate or tereré; this species is listed as a substitute for K. odorata Vahl (Cyperaceae), validated as medicinal and used, among others, in the treatment of leukorrhea. In the present work, the antifungal and antibiotic activities were tested, in order to evaluate the potential against leukorrhea.
\end{abstract}

Keywords: Kyllinga vaginata; Kapi'́katĩ; Cyperaceae; Paraguay; Leucorrhea; Antifungal and antibiotic activities

\section{Introduction}

In recent decades, researchers have focused on drug discovery from medicinal plants, an important group of complementary and alternative medicine (CAM) therapies. Because plants have long been used for the clinical management of various diseases in indigenous cultures, the success rate of developing a new drug from herbal medicinal preparations should, in theory, be higher than that of chemical synthesis. Paraguay, like many Latin American countries, has a rich tradition in the use of medicinal plants for the treatment of several types of ailments [1]. The majority of the population consumes medicinal plants on a daily basis for the treatment of various ailments or simply as a custom related to the consumption of mate or tereré, a ritual that makes Paraguay one of the countries with the highest consumption of herbal medicines in tea form in the world [2].

The yuyeras sell bunches of «kapi'ikati» in the markets, which are consumed in mate or tereré for their digestive, diuretic, sedative, tonic, antispasmodic and/or sudorific properties [3]. They are also used to treat problems of vaginal discharge (leucorrhea) [4]. In these clumps are the rhizomes of four different species all belonging to the family Cyperaceae. Three of them belong to the genus Kyllinga: Kyllinga odorata Vahl, Kyllinga brevifolia Rottb., Kyllinga vaginata Lam. (Figure 1) and the last one to the genus Scleria: Scleria distans Poir. Nevertheless, all these species are called «kapi'ikatí», because collectors confuse them for their morphological similarities and for sharing the habitat. The species, whose rhizome use is validated as medicinal under this popular name, is Kyllinga odorata Vahl [5]. The unambiguous botanical identification of the species is therefore of utmost importance.

Given the medicinal use and the lack of knowledge about «kapi'ikati», this work focuses on determining the antimicrobial activities of the native species Kyllinga vaginata Lam. highlighting the activity against Candida albicans, one of the causative agents of leucorrhea, in order to justify one of its popular uses.

\section{Material and Methods}

\section{Sampling}

The collection of the material recognized as «kapi'ikati blanco», which is characterized by the white ending of the rhizome, which grows in the city of Ypacaraí of the Central 
Department, Paraguay, $25^{\circ} 22^{\prime} 59.88^{\prime \prime}$ S-57 $16^{\circ} 0.12^{\prime \prime} \mathrm{W}$, was carried out with the help of the «yuyeras» of the zone. The collected specimens were in a reproductive state, an essential condition for taxonomic identification. The control materials were deposited in the FACEN herbarium of the Laboratory of Analysis of Plant Resources (LAREV) of the Department of Biology, Faculty of Exact and Natural Sciences, National University of Asuncion, under the following denomination:
PARAGUAY. Central Department. Ypacaraí, M.E.Blanc 1, 28-I2016. (FACEN)

PARAGUAY. Central Department. Ypacaraí, M.E.Blanc 2, 28-I2016. (FACEN)

PARAGUAY. Central Department. Ypacaraí, M.E.Blanc 3, 28-I2016. (FACEN)

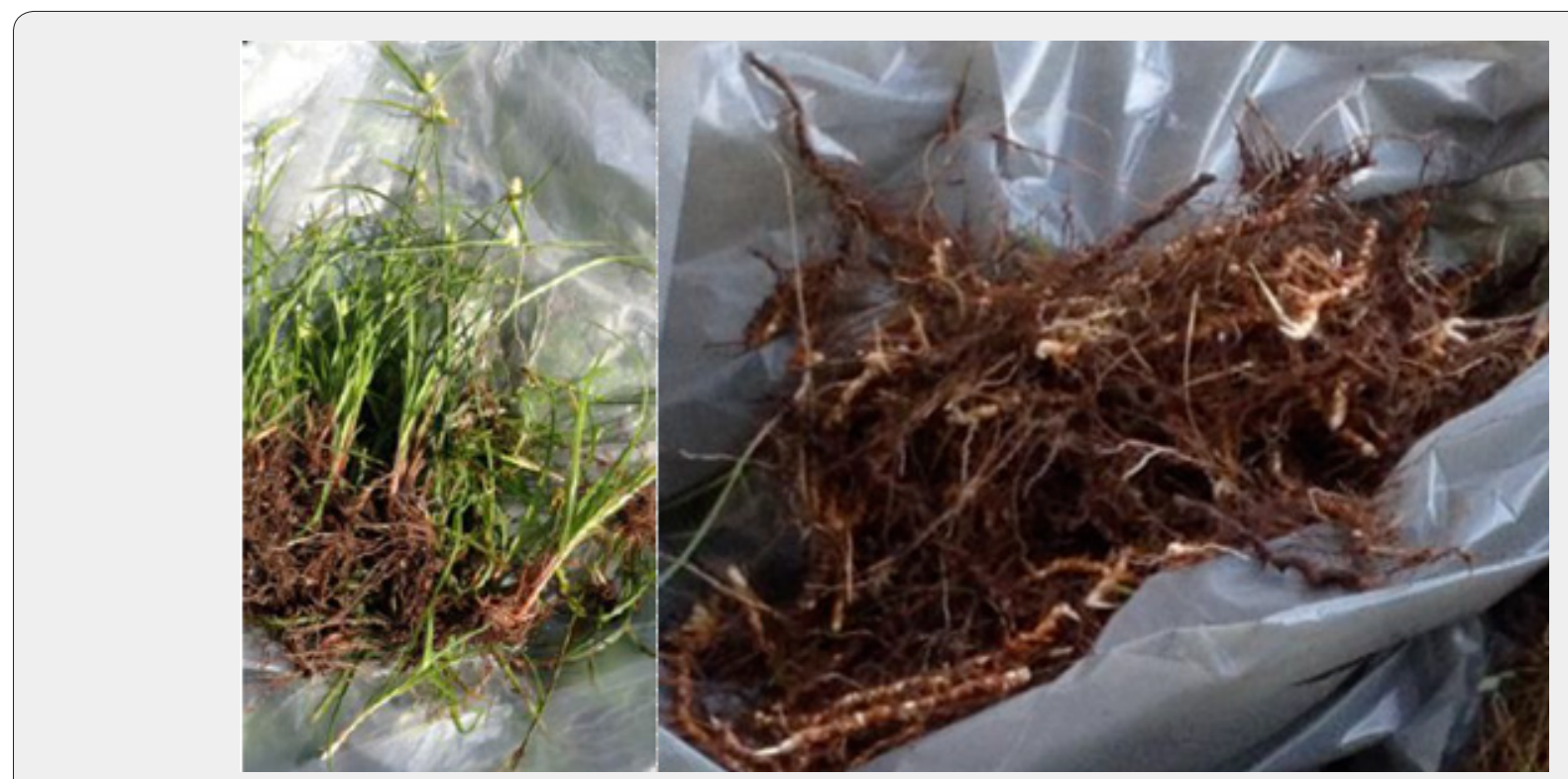

Figure 1: Rizhomes of Kyllinga vaginata Lam.

\section{Taxonomic identification}

Taxonomic identification was carried out with the collaboration of a botanical specialist, Bonifacia Benítez at the Laboratory of Analysis of Plant Resources-Herbarium FACEN.

\section{Preparation of plant material to obtain the crude extract}

The collected plant specimen, free of sand and other contaminants, was dried at room temperature, protected from light and moisture [6]. After drying, the rhizome was separated from all the aerial part and the roots, since it is rhizome that is the part used in folk medicine. The rhizome was chopped and then ground using a screw mill and $6.505 \mathrm{~kg}$ of powder was obtained for efficient extraction of the chemical compounds present [7]. $6.0 \mathrm{~kg}$ of the grind was used to perform the extraction and $0.505 \mathrm{~kg}$ was stored in closed containers in a dark, cool and dry place.

\section{Obtaining the crude extract (KYC)}

$6.0 \mathrm{~kg}$ of crushed rhizomes were subjected to maceration with 50 liters of $96^{\circ}$ ethyl alcohol for a period of 30 days, with agitation at least three times a week $[7,8]$. Two more extractions were repeated with 15 days of rest per extraction. Gravity filtration was performed and then the solvent was evaporated under reduced pressure in a rotary evaporator. The resulting crude extract was stored in a glass bottle and kept at $4^{\circ} \mathrm{C}$ until analysis. The extraction yield was calculated.

\section{Biological activity, antimicrobial activity}

The disk diffusion test was performed according to the guidelines of «Clinical \& Laboratory Standards Institute» [9]. The following concentrations of the crude extract were tested: 20.12; 25.15 and $30.18 \mathrm{mg} \mathrm{mL}^{-1}$ and dimethylsulfoxide (DMSO) was used as the solvent.

\section{The microorganisms used for the test were as follows gram-negative strains:}

Escherichia coli (ATCC 8739), Salmonella typhimurium (ATCC 14028), Enterococcus faecalis (ATCC 29212) and Pseudomonas aeruginosa (ATCC 27853); gram-positive: Staphylococcus epidermidis (ATTC 12228), Staphylococcus aureus (ATCC 29737); Yeast: Candida albicans (ATTC 10231) and filamentous fungus: Aspergillus braziliensis (ATTC 16404).

For the test, the strains were treated and then suspended to a turbidity of $0.5 \mathrm{Mc}$ Farland. Müller Hilton agar (MHA) was used for bacteria and Sabouraud agar (SA) for fungi. The different microorganisms were inoculated with a sterile cotton swab.

Solutions of $10 \mathrm{mg} \mathrm{mL}^{-1}$ of the antimicrobials mentioned below were prepared and $10 \mu \mathrm{L}$ were inoculated onto the disk: 
Amphotericin B positive control for Candida albicans, Meropenen for Salmonella typhimurium and Escherichia coli, and Amphotericin B for Aspergillus braziliensis. For the other strains, commercial antibiotic disks were used: Cefoxitin for Staphylococcus aureus and Staphylococcus epidermidis, Vancomycin for Enterococcus faecalis, and Ceftazidime for Pseudomonas aeruginosa.

The extract solutions, positive and negative controls were inoculated with sterile qualitative filter paper discs (Whatman grade 1). Each disc was impregnated with $10 \mu \mathrm{L}$.

Five discs were distributed on each plate: three corresponding to the different mentioned concentrations of the extract, one positive control, and one negative control. The AMH plates were incubated in an oven at $37^{\circ} \mathrm{C}$ for 24 hours and the AS plates at $27^{\circ} \mathrm{C}$ for 5 days. Antimicrobial activity was determined by measuring the diameter of inhibition («halo of inhibition») produced around each disc. All tests were performed in triplicate.

\section{Results and Discussion}

\section{Taxonomic identification}

Bonifacia Benitez of the Plant Resources Analysis Laboratory - FACEN Herbarium determined that the collected specimen is Kyllinga vaginata Lam.

\section{Obtaining the crude extract (KYC)}

The extraction yield was 5.88\% (353g).

\section{Biological activity, Antimicrobial activity}

Diffusion disc test: all three tested concentrations of the crude extract showed negative results (Table 1), i.e. the extracts did not show activity against Candida albicans, Staphylococcus epidermidis, Enterococcus faecalis, Pseudomonas aeruginosa, Staphylococcus aureus, Salmonella typhimurium, Escherichia coli and Aspergillus braziliensis. The tests were performed in two different laboratories and the same negative result was obtained for all strains tested.

Table 1: Disc diffusion test results for antimicrobial activity. References: $\mathrm{C} 1: 20.12 \mathrm{mg} \cdot \mathrm{mL}^{-1} ; \mathrm{C} 2: 25.15 \mathrm{mg} \cdot \mathrm{mL}^{-1} ; \mathrm{C}: 30.18 \mathrm{mg} \cdot \mathrm{mL}^{-1}$.

\begin{tabular}{|c|c|c|c|}
\hline \multirow{2}{*}{ Microorganisms } & \multicolumn{3}{|c|}{ Inhibition Halo Measurement (mm) } \\
\cline { 2 - 4 } & \multicolumn{3}{|c|}{ KYC } \\
\cline { 2 - 4 } & C1 & C2 & $0 \pm 0$ \\
\hline Candida albicans & $0 \pm 0$ & $0 \pm 0$ & $0 \pm 0$ \\
\hline Staphylococcus epidermidis & $0 \pm 0$ & $0 \pm 0$ & $0 \pm 0$ \\
\hline Enterococcus faecalis & $0 \pm 0$ & $0 \pm 0$ & $0 \pm 0$ \\
\hline Pseudomonas aeruginosa & $0 \pm 0$ & $0 \pm 0$ & $0 \pm 0$ \\
\hline Staphylococcus aureus & $0 \pm 0$ & $0 \pm 0$ & $0 \pm 0$ \\
\hline Salmonella typhimurium & $0 \pm 0$ & $0 \pm 0$ & $0 \pm 0$ \\
\hline Escherichia coli & $0 \pm 0$ & $0 \pm 0$ & \\
\hline Aspergillus braziliensis & $0 \pm 0$ & & 0 \\
\hline
\end{tabular}

Among the studies available in the literature for species of the same genus, there is the study of antimicrobial activity of methanolic extract of Kyllinga nemoralis in which the authors mention that it has inhibitory activity against $S$. aureus, E. faecalis $[10,11]$.

\section{Conclusion}

One of the species marketed as «kapi'i kati» is Kyllinga vaginata Lam. The crude extract (ethanolic extract) did not show antimicrobial activity against Candida albicans under the test conditions, which is why we cannot guarantee the use of this species as a substitute for the original for the treatment of leucorrhea.

\section{Acknowledgment}

This study was supported by the projet PO-FEDER AGROECODIV.

\section{References}

1. Degen De Arrúa RL, González Villalba YP, Amarilla A (2009) Legislación sobre plantas medicinales y fitoterápicos en Paraguay: Una tarea pendiente. Boletín Latinoamericano y Del Caribe de Plantas Medicinales y Aromáticas. 8(1): 12-16.

2. Pin A, Gonzalez G, Marin G, Céspedes G, Cretton S, et al. (2009) Plantas Medicinales. In: A Pin, G Céspedes (Eds.), (Primera). Asunción: Asociación Etnobotánica Paraguaya.

3. Helión-Ibarrola MC, Montalbetti Y, Heinichen OY, Kennedy ML, Campuzano MA, et al. (2016) Antidepressant-like effect of Kyllinga brevifolia rhizomes in male mice and chemical characterization of the components of the active ethyl acetate fraction. Journal of Ethnopharmacology 194: 1005-1011.

4. Degen De Arrua RL, Cespedes De Zárate CI, González YP, González Zalema G, Délmas De Rojas GE, et al. (2011) Catalogo Ilustrado de 80 plantas medicinales del Paraguay.

5. Gonzalez Y, Mercado MI, Degen R, Ponessa GI (2009) Morfoanatomía y etnobotánica de rizoma, tallo y escapo de " kapi' i kati", Kyllinga odorata (Cyperaceae) y sus sustituyentes de Asunción del Paraguay y alrededores. 46: 58- 67. 
6. Martinez M, Mancuello C, Britez F, Pereira C, Arrua J, et al. (2012) Caracterización química y actividades biológicas de lapachol aislado de Handroanthusheptaphyllus (Vell.) Mattos. Steviana (PRY) 4: 47-64.

7. Martínez M, Mancuello C, Pereira C, González F, Prieto R, et al. (2014) Estudio espectrofotométrico de la actividad hemolítica del extracto crudo de Phoradendron bathyoryctum Eichler sobre eritrocitos humanos. Steviana (PRY) 5: 114-121.

8. González A (2004) Obtención de aceites escenciales y extractos etanolicos de plantas del amazonas (Tesis de grado). Universidad Nacional de Colombia, Colombia.
9. CLSI (2012) Clinical and Laboratory Standards Institute.

10. Sindhu T, Rajamanikandan S, Srinivasan P (2014루) In vitro Antioxidant and Antibacterial Activities of Methanol Extract of Kyllinga nemoralis. Indian Journal of Pharmaceutical Sciences 76(2): 170-174.

11. Si-Yuan P, Shu-Feng Z, Si-Hua G, Zhi-Ling Y, Shuo-Feng Z, et al. (2013) New Perspectives on How to Discover Drugs from Herbal Medicines: CAM's Outstanding Contribution to Modern Therapeutics. Hindawi Publishing Corporation. Evidence-Based Complementary and Alternative Medicine 2013(627375): 25.

\section{Your next submission with Juniper Publishers} will reach you the below assets

- Quality Editorial service

- Swift Peer Review

- Reprints availability

- E-prints Service

- Manuscript Podcast for convenient understanding

- Global attainment for your research

- Manuscript accessibility in different formats ( Pdf, E-pub, Full Text, Audio)

- Unceasing customer service

Track the below URL for one-step submission https://juniperpublishers.com/online-submission.php 